\title{
The Relationship between Entrepreneurial Culture and Sustainable Competitive Advantage in the
} Banking Sector

\author{
Sulaiman Olusegun Atiku, * Ziska Fields \\ College of Law and Management studies, University of KwaZulu-Natal, Durban, South Africa \\ *fields@ukzn.ac.za
}

\begin{abstract}
Business sustainability of services-rendering organisations is one of the major concerns for those at managerial levels world-wide. This paper offers explanations on how best to achieve sustainable competitive advantage by communicating entrepreneurial values through human resource development programmes in the banking industry. The research reported in this paper adopted a non-experimental research design of ex post facto type, utilising a correlational approach with advanced explanatory design. Based on the principle of convenience sampling, 380 questionnaires were distributed to employees of two Nigerian banks. Three hypotheses were formulated and tested using inferential statistics via two statistical software packages: the IBM Statistical Package for Social Science (SPSS) version 23 and the IBM SPSS Analysis of Moment Structure (AMOS) version 23. The results show that human resource development partially mediates the relationship between entrepreneurial culture and sustainable competitive advantage in the Nigerian banking sector. The results suggest an enhancement of entrepreneurial values through continuous learning and development programmes toward sustainable competitive advantage. It is recommended that sustainability of banks operating in Nigeria could be enhanced by communicating and managing entrepreneurial orientations through effective learning and development programmes. Ambidextrous banks will require creativity, innovation and proactive capabilities in the process of exploiting and exploring both current and future business opportunities for sustained competitive advantage.
\end{abstract}

Keywords: Business sustainability, Corporate Entrepreneurship, Creativity and Innovation, Human Resource Development, Knowledge-Based View (KBV)

\section{Introduction}

Integration of the world economy as dictated by rapidly changing technological innovations has affected virtually all areas of life and business operations across the globe (Daneshvar \& Ramesh, 2011). This trend has posed a series of challenges to organisations operating in the turbulent business environment (Atiku, Chitakunye, \& Fields, 2014b). In specific terms, the sustainability of organisations in the service industry is at risk. This is due to changes in the external business environment. In terms of technological innovations, customer tastes and demands, customers' satisfaction and retention, series of banking reforms, as well as economic and political instability are causes for concern. These external environmental factors pose challenges to the achievement of a sustainable competitive advantage of commercial banks operating in the Nigerian banking industry as well. For instance, a series of banking reforms by the Central Bank of Nigeria (CBN), which were intended to improve the banking operations in Nigeria (Sanusi, 2012), became an issue for commercial banks operating in the country. Commercial banks at the receiving end are confronted with the need to simultaneously respond to technological innovations, customer tastes and demands, customer retention and series of banking reforms. A new way of thinking is needed for banks to ensure their sustainable competitiveness and this will require a new focus on organisational culture and human resources.

Sustainable competitive advantage in the current global economy requires entrepreneurial behaviour patterns and entrepreneurial orientations by managers and employees in responding to the variations in various business environments. This can be referred to as Corporate Entrepreneurship (CE), which provides a potentially viable means for promoting and sustaining corporate competitiveness (Covin\& Miles, 1999). CE enables an individual or a group of individuals, in association with an existing organisation, to create new organisations, instigate renewal and/or innovate within that organisation. The development of CE however 
requires a holistic commitment to building the capacity and environment for corporate performance and competitiveness (Moreno \& Casillas, 2008; Nkosi, 2011). An entrepreneurial organisation institutionalises practices that create a supportive organisational environment that builds commitment and ensures that technical and business skills are utilised to behave more entrepreneurially (Anderson, 1992; Russell, 1999). This has an impact on the overall culture of the organisation which influences individuals' willingness to accept entrepreneurial change and become more entrepreneurial (Floyd \& Wooldridge, 1999). The organisation culture can then become a source of sustained competitive advantage.

To achieve sustainability, those entrepreneurial behaviour patterns and entrepreneurial orientations could be communicated through continuous learning and development programmes in line with business needs and/or strategies to enhance innovative, proactive and risk-taking abilities, thereby leading to competitive advantage (Beugelsdijk, 2007; Boso, Story, \& Cadogan, 2013; Engelen, 2010; Huang \& Wang, 2011; Keh, Nguyen, \& Ng, 2007; Li, Huang, \& Tsai, 2009; Lisboa, Skarmeas, \& Lages, 2011; Martin, McNally, \& Kay, 2013; Pérez-Luño, Wiklund, \& Cabrera, 2011). Management especially plays a critical role in the communication and management process to create an entrepreneurial culture in organisations. Judging from the literature, most studies on the link between entrepreneurial culture and competitive advantage were conducted in developed countries.

Objectives: The primary objective of the research on which this paper is based was to investigate the relationship between entrepreneurial culture and sustainable competitive advantage in the banking sector using Nigerian banks. It also probed the extent to which human resource development mediates the relationship between entrepreneurial culture and sustainable competitive advantage in the banking sector. The explanation of the mediating influence of learning and development on the link between entrepreneurial culture and sustainable competitive advantage in the banking industry was statistically analysed using structural equation modelling.

The theoretical framework and hypotheses: The knowledge-based view (KBV) of the firm was adopted as theoretical framework for this study whilst exploring the interplay between entrepreneurial culture and sustainable competitive advantage in the banking sector with specific reference to Nigerian banks. Insights gained from the KBV of the firm suggest that knowledge creation could be used as a source for sustainable competitive advantage (Grant, 1996; Hung, Yang, Lien, McLean, \& Kuo, 2010; Pollitte, Miller, \&Yaprak, 2015). Knowledge is acquired and transferred at three major levels in an organisation, namely at individual, team and organisational levels (Hung et al., 2010; Pollitte et al., 2015; Wang, Yang, \& MacLean, 2007; Watkins \& Marsick, 1993, 2003). Drawing insights from the foregoing, this paper explores the mediating influence of human resource development programmes on the entrepreneurial orientations - sustainable competitive advantage link. The outcomes will be valuable in proposing ways to communicate and develop entrepreneurial orientations among employees, in order to achieve business sustainability in the banking sector. The theoretical framework is illustrated in Figure 1.

Figure 1: The conceptual framework for the relationship between entrepreneurial culture and sustainable competitive advantage

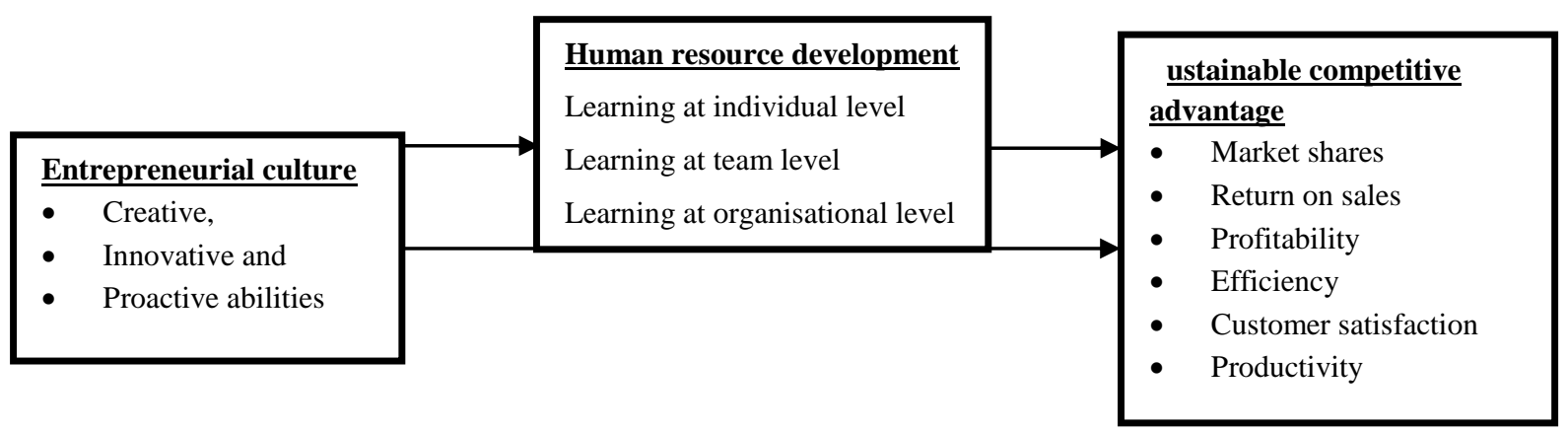


To enable proper statistical analysis of the propositions in this paper, the following hypotheses were formulated in line with the conceptual framework and objectives of the study:

$\mathrm{H}_{0}$. There is no significant relationship between entrepreneurial culture and human resource development programmes.

$\mathrm{H}_{1}$. There is a significant relationship between entrepreneurial culture and human resource development programmes.

$\mathrm{H}_{0}$. There is no significant relationship between entrepreneurial culture and sustainable competitive advantage.

$\mathrm{H}_{2}$. There is a significant relationship between entrepreneurial culture and sustainable competitive advantage.

$\mathrm{H}_{0}$. Human resource development programmes do not mediate the relationship between entrepreneurial culture and sustainable competitive advantage in the Nigerian banking industry.

$\mathrm{H}_{3}$. Human resource development programmes mediate the relationship between entrepreneurial culture and sustainable competitive advantage in the Nigerian banking industry.

\section{Literature review}

This section provides an overview of related literature on the link between human resource development and entrepreneurial orientations in relation to business sustainability in the present knowledge-based global economy. The influence of learning and development in creating and sharing dynamic capabilities as strategic measures or coping strategies for sustainable competitive advantage are also explored.

Human resource development: Armstrong (2009) refers to human resource development as the process of acquiring and developing knowledge, skills, capabilities, behaviours and attitudes through learning or developmental experiences. Mello (2011), on the other hand, maintains that learning and development are focused on micro-aspects of firm needs and responsiveness, and that organisational development takes a holistic approach or is focused on macro-aspects of firm needs and responsiveness to environmental variations to boost corporate performance. Hence, developing and enhancing creative, innovative and proactive abilities of human resources at an organisational level in line with the business strategies and environmental variations are essential for business sustainability (Mello, 2011). This suggests why Sanzvalee et al. (1999, cited in Katou \& Budhwar, 2010) claim that organisations with innovative strategies make huge investments on development of core employees towards the realisation of desired business plans and objectives.

Similarly, Mondy (2010) refers to human resource development as update of knowledge, skills and abilities aimed at improving individuals' or groups' competence, as well as operational outcomes. This implies that continuous investment in knowledge, skills and dynamic capabilities leading to operational effectiveness and efficiency are necessary for sustainable competitive advantage in the service industry. Knowledge management is one of the fundamental strategies for sustainable competitive advantage in the knowledgebased global economy (Goel, Rana, \& Rastogi, 2010; Mundra, Gulati, \& Vashisth, 2011). An empirical evidence from a study in India shows that the development of electronic banking applications or platforms through learning and development is responsible for higher service quality and customer satisfaction leading to sustainable competitive advantage (Daneshvar \& Ramesh, 2011). However, there is a dearth of literature or empirical evidence on the relationship between entrepreneurial culture and sustainable competitive advantage in the Nigerian banking sector. This was the basis or rationale for the study reported in this paper.

Corporate entrepreneurship: Corporate entrepreneurship (CE) can be defined as the sum of a company's efforts aimed at innovation, pro-activeness and risk taking (Zahra \& Garvis, 2000). It can be used to enhance company performance (Lumpkin \& Dess, 1996) by making full use of its resources to capture new opportunities (Yiu \& Lau, 2008). CE is a very important aspect of an organisation's activities and requires continuous investment in knowledge and skill development from a human resources perspective, as well as in creating an entrepreneurial culture in an organisation. The key to success is determined by how well an 
organisation, for example a bank in Nigeria, can welcome the entrepreneurial individual into the "banking family' and enable the individual to contribute to the value creation process of the bank (Mahadea \& Youngleson, 2013). CE involves the birth of new businesses within existing organisations; and creates the internal transformation of organisations (Dess, Lumpkin, \& McGee, 1999). Table 1 shows the four forms of CE as well as the typical basis for competitive advantage, the frequency of new entrepreneurial acts and the impact if entrepreneurial acts are unsuccessful.

Table 1 show that a bank, for example, can differentiate itself by creating new products and services. However, to continuously create new products and services to ensure sustained differentiation and competitive advantage requires continuous efforts by employees. In addition, the quick adaptation ('leapfrogging') by other banks will not have a detrimental negative impact on the bank or its employees in their entrepreneurial acts, although the leapfrog strategy can present a difficult challenge overall for the bank due to the substantial or transformational innovation needed (Aaker, 2012). For a bank to streamline internal processes in an effort to cut costs, modify its resource base and remain competitive requires a new strategic direction or major, internally focused innovation to improve operations and strategy implementation. The frequency of entrepreneurial acts is less than the focus on differentiation through new products and services. The impact of failed entrepreneurial attempts are also more severe when such attempts are focused on strategic renewal or organisational rejuvenation, because of their impact on underlying processes, rules, routines and resources, along with the capabilities to develop and execute such activities (Rothaermel \& Hess, 2007).

\section{Table 1: Forms of corporate entrepreneurship}

\begin{tabular}{|c|c|c|c|c|}
\hline $\begin{array}{l}\text { Form of corporate } \\
\text { entrepreneurship }\end{array}$ & $\begin{array}{l}\text { Focus of corporate } \\
\text { entrepreneurship }\end{array}$ & $\begin{array}{l}\text { Typical basis for } \\
\text { competitive } \\
\text { advantage }\end{array}$ & $\begin{array}{l}\text { Typical frequency of } \\
\text { new entrepreneurial } \\
\text { acts }\end{array}$ & $\begin{array}{l}\text { Magnitude of } \\
\text { negative impact if } \\
\text { entrepreneurial act } \\
\text { is unsuccessful }\end{array}$ \\
\hline $\begin{array}{l}\text { Sustained } \\
\text { regeneration }\end{array}$ & $\begin{array}{l}\text { New products or new } \\
\text { markets }\end{array}$ & Differentiation & High frequency & Low \\
\hline $\begin{array}{l}\text { Organisational } \\
\text { rejuvenation }\end{array}$ & The organisation & Cost leadership & Moderate frequency & Low-to-moderate \\
\hline Strategic renewal & Business strategy & $\begin{array}{l}\text { Varies with specific } \\
\text { form manifestation }\end{array}$ & Less frequent & Moderate-to-high \\
\hline Domain redefinition & $\begin{array}{l}\text { Creation and } \\
\text { exploitation of } \\
\text { product/market } \\
\text { arenas }\end{array}$ & Quick response & Infrequent & $\begin{array}{l}\text { Varies with specific } \\
\text { form manifestation } \\
\text { and contextual } \\
\text { consideration }\end{array}$ \\
\hline \multicolumn{5}{|c|}{$\begin{array}{l}\text { Notes: } \\
\text { New entrepreneurial acts for: } \\
\text { - Sustained regeneration: a new product introduction or the entrance of a new (to the firm) but existing market; } \\
\text { - Organisational rejuvenation: a major, internally focused innovation aimed at improving firm functioning or strategy implementation; } \\
\text { - Strategic renewal: the pursuit of a new strategic direction; and } \\
\text { - Domain redefinition: the creation and exploitation of a new, previously unoccupied product/market arena. }\end{array}$} \\
\hline
\end{tabular}

Source: Covin\& Miles (1999)

CE is a viable way to develop and sustain corporate competitiveness and profitability (Covin \& Miles, 1999 cited in Nkosi, 2011) to enable large companies (like banks) to survive in a turbulent global economy (Lumpkin \& Dess, 1996 cited in Nkosi, 2011). The organisational entrepreneurial thinking must be generated from within the organisation and should be reflected in how the organisation interacts with itself and its competitive environment (Mahadea \& Youngleson, 2013), and especially how the organisation interacts with its human resources to encourage and reward innovation, creativity, pro-activeness and competitive aggressiveness. An entrepreneurial culture is therefore critical for CE to be successful.

Entrepreneurial culture: Corporate culture can either drive or hinder strategic and business agendas, according to the Principia Group (2011). The group explain this view by showing that in a recent study on 
culture among 300 European banks it was estimated that if banks want to succeed, the human orientation of the banks' cultures must be increased by $10 \%$ to have a positive impact on performance. However, the corporate culture of most banks favours conservatism and is restrictive, and approach that does not lend itself to CE (Mahadea \& Youngleson, 2013). Yet, after the financial meltdown in 2008, the focus on preventing another bank crisis has shifted from just focusing on regulation to a more sustainable solution that can be found in the corporate culture of banks. The Principia Group $(2001$, p. 2) states that they "strongly believe that reshaping corporate culture, in conjunction with prudent regulatory changes can work together to help build a stronger, more responsive and responsible banking industry". The focus on corporate culture also requires a critical review of entrepreneurial culture to build high-performance corporate cultures.

Entrepreneurial culture points to orientations leading to creativity, innovation and higher level of competence or skills (Deshpandé \& Farley, 2004). The competitive and entrepreneurial values are related to market orientations offered by Cameron, Quinn, DeGraff, and Thakor (2006)as one of the strategies required for adjusting to variations in the global economy. The modern-day knowledge-based economy requires cultural dimensions that are flexible, relative to adjusting to the variations in the business environments (Cheung, Wong, \& Lam, 2012). This explains why Fayolle, Basso, and Bouchard (2010) argue that it is difficult to ignore the influence of environment on the values system, activities and behaviours of most business organisations across the globe. In the course of establishing the environmental influence on core values and commercial banks outcomes, Atiku (2014) investigated the relationship between organisational culture and performance in the Nigerian banking sector. The results show that entrepreneurial orientation as a dimension of corporate culture made considerable contributions to the effectiveness of commercial banks in Nigeria. Sudarmo (2013), on the other hand, argues that internal and external activities of business organisations have significant influence on organisational outcomes. This shows that entrepreneurial values are essential for service organisations (like banks) that are willing to remain in business in the present economy. However, continuous enhancement of creative, innovative and proactive abilities among service organisations will determine how far any organisation can go in the present business environments characterised by vast technological innovations. Entrepreneurial orientations are instrumental in eliciting prompt reactions to changes in customer tastes leading to customer satisfaction and retention as antecedents of sustainable competitive advantage (Daneshvar \& Ramesh, 2011). The reason is that the survival of any service organisation is largely dependent on its market orientations to ensure total customer satisfaction, loyalty and retention.

Specifically, for a bank to remain competitive in terms of market share and customer retention, its entrepreneurial orientations must be given higher priority (Sevrani, Gorica, \& Kordha, 2013). This implies that for banks to remain in business in the knowledge-based global economy, concerted efforts have to be made towards the development of new products and services in line with the current and future needs of their customers. There have to be high levels of innovative and creative mind-sets for business process improvement (Harrington, 1991; Bhatt, 2000; Zivanovic \& Zivanovic, 2015) or re-engineering (Shihab \& Lestari, 2014; Mashhadi, Azar, \& Shahin, 2015) in line with the market orientations in the global economy. The creative and innovative values are communicated through continuous learning and development programmes in line with the business needs and strategies (Daneshvar \& Ramesh, 2011; Goel, Rana, \& Rastogi, 2010; Mondy, 2010; Mundra, Gulati, \& Vashisth, 2011). This points to the association between entrepreneurial culture and human resource development programmes. The extent to which human resource development programmes mediate the relationship between entrepreneurial culture and competitive advantage in the banking sector is also a gap that needed to be filled in the current study. Human resource development does not only mediate the relationship but also develops an entrepreneurial mindset which is critical in creating and maintaining a sustained competitive advantage.

Sustainable competitive advantage: According to Porter (1985, cited in Liu (2013) sustainable competitive advantage in the knowledge-based global economy refers to business plans or strategies embarked upon by an organisation to excel, in terms of efficiency, quality output, market shares and customer retention. Liu (2013) on the other hand, holds that sustainable competitive advantage has to do with the ability to develop a fast strategy and its implementation through the outcomes of continuous learning and development programmes in order to stand out or the first to be reckoned with in the chosen area of business. This shows 
that human capital can be seen as a unique source of sustainable competitive advantage since efforts toward sustainability largely depend on the effective utilisation of human resources, leading to returns on sales, market shares, customer retention, efficiency, and productivity (Daneshvar \& Ramesh, 2011; Goel et al., 2010; Mundra et al., 2011). Business sustainability of services-rendering organisations is one of the major concerns for those at managerial levels world-wide. For example, recent study conducted by Evans (2016) and Della Corte and Aria (2016) in the service industry revealed that to remain in business, those at the managerial cadres need to be conscious of the characteristics of services in the industry and strategic alignment of management principles. Competitive advantage of service-rendering organisations would be useful in achieving sustainable economic growth in Nigeria

Furthermore, Srivastava, Franklin, and Martinette (2013) claim that to ensure business sustainability, organisations must continuously focus on the design and implementation of product or service strategies, continuous shaping of dynamic capabilities, development or acquisition of technologies, and human assets. These factors are essential for business sustainability in the knowledge-based global economy. For Macfarlane (2014), business sustainability in the $21^{\text {st }}$ century involves organisational access to internal and external knowledge acquisition, as well as other valuable resources. This suggests why Wang, Lin, and Chu (2011) state that business organisations that focus on the acquisition of unique resources in terms of human capital and other valuable resources, and rely on expert knowledge in its day-to-day business activities, outsmart their competitors. Therefore, the current paper's focus on examining entrepreneurial orientations through knowledge and skills acquisition and as a source of sustainable competitive advantage in the banking sector is important.

\section{Methodology}

Research approach: The research methodology was designed to investigate the relationship between entrepreneurial culture and sustainable competitive advantage, as well as the extent to which human resource development mediates the relationship between entrepreneurial culture and sustainable competitive advantage in the banking sector. The explanation of the mediating influence of learning and development on the link between entrepreneurial culture and sustainable competitive advantage was statistically analysed using structural equation modelling.

Respondents and sampling: This research investigated five competitive banks in Lagos, which is the commercial nerve centre of Nigeria. The estimated research population was 5387 employees across various levels. Using the convenience sampling technique, 380 questionnaires were evenly distributed between two participating banks. A total of 190 questionnaires were distributed in each bank's head office and the selected branches in Lagos. Branches of the participating banks in Lagos were selected using the simple random sampling technique. At the end of 12 weeks of distribution and follow-up, a total of 306 questionnaires were returned. One of the questionnaires was not properly completed and was left out of the analysis. However, the remaining 305 questionnaires represent an $80.3 \%$ response rate.

Measuring instrument: The measurement instrument was developed based on the adaptation of the following:

- The Organisational Culture Scale (OCS) to explore the entrepreneurial culture construct;

- The Dimensions of Learning Organisation Questionnaire (DLOQ) to explore the HRD construct;

- The Dimensional scale developed by Baker and Sinkula (1999), as adapted by Hung et al. (2010), to explore the sustainable competitive advantage construct.

The choice of each developed instrument in this study was based on the reliability and validity of the instrument. The wide acceptance and applicability of the instruments in the context of the Nigerian banking sector also influenced the decisions. Measures of the three major constructs investigated in this paper are discussed below.

Entrepreneurial culture: The construct entrepreneurial culture was adapted from the OCS developed by Deshpande and Farley (1999). OCS is a four-dimensional scale consisting of 16 items on a 5-point Likert-type 
rating scale ranging from 1 (strongly disagree) to 5 (strongly agree). The scale was also adapted in Nigeria by Ezirim, Nwibere, and Emecheta (2010), as well as Nwibere (2013). The reliability of the instrument in Asian and African countries ranges from 0.814 to 0.877 (Deshpande \& Farley, 1999; Ezirim et al., 2012; Nwibere, 2013). A dimension of OCS was adapted in this study measuring entrepreneurial culture with four items on a 4-point Likert-type rating scale ranging from 1 (strongly disagree) to 4 (strongly agree). Neutral as an option in the rating scale was left out because employees cannot be neutral on the core values shaping their attitudes and work behaviours. The Cronbach's alpha coefficient for the four items measuring entrepreneurial culture was 0.807. This is reliable, based on the rule of thumb offered by George and Mallery (2003) and Pallant (2011).

Human resource development (HRD): The construct HRD was measured in this study by adapting the Dimensions of Learning Organisation Questionnaire (DLOQ) developed by Watkins and Marsick (2003). This is a three-dimensional scale measuring HRD at individual, team and organisational levels on a 6-point Likerttype rating scale; ranging from 1 (strongly disagree) to 6 (strongly agree). The Cronbach's alpha coefficients for HRD at individual, team and organisational levelswere $0.81,0.80$ and 0.88 respectively (Watkins \& Marsick, 2003). The alpha coefficient for the entire scale consisting of 16 items was 0.93 . In the current study this measuring instrument was considered valuable in the quest to explore the influence of HRD programmes on the link between entrepreneurial orientations and sustainable competitive advantage in the banking sector. The three-dimensional scales of DLOQ with 16 items was adapted in this study on a 4-point Likerttype rating scale, ranging from 1 (strongly disagree) to 4 (strongly agree). The Cronbach's alpha coefficient for the 16 items of DLOQ in the Nigerian banking sector was 0.914 , while the dimensional alpha coefficients for individual, team and organisational learning were $0.806,0.804$ and 0.828 respectively (Atiku, Chitakunye, \& Fields, 2014a). This suggests reliable internal consistency based on the rule of thumb proposed by George and Mallery (2003) and Pallant (2011).

Sustainable competitive advantage: The construct sustainable competitive advantage was measured in this study with a dimensional scale with six items of organisational performance in relation to the performance of major competitors in the last three years. The scale was developed by Baker and Sinkula (1999), as adapted by Hung, Yang, Lien, McLean, and Kuo (2010). The scale was developed on a 5-point Likert-type rating scale ranging from 1 (strongly disagree) to 5 (strongly agree). The Cronbach's alpha for this scale was 0.88 . The scale was adapted in this current study in order to measure competitive advantage: market share, profitability, efficiency, return on sales and customer satisfactionrelative to the participating organisation's major competitors in the Nigerian banking sector. The measuring instrument was adapted on a 4-point Likert-type rating scale. The internal consistency for the six items on the sustainable competitive advantage construct in this study was 0.821 . This is also reliable based on the rule of thumb provided by George and Mallery (2003) and Pallant (2011).

Data analysis procedures: The formulated hypotheses were analysed using inferential statistics via two statistical software packages. The IBM Statistical Package for Social Science (SPSS) version 23 was valuable in running bivariate correlations between the variables, as well as statistical reliability and validity of the measuring instrument. The IBM SPSS statistics AMOS version 23 was also instrumental in running structural equation modelling (SEM). This enables a robust statistical analysis in order to provide adequate explanations on the mediating influence in the link between entrepreneurial culture and sustainable competitive advantage. Three latent variables were included in the measurement and structural models: entrepreneurial culture served as an exogenous variable, and human resource development policy and sustainable competitive advantage played the roles of endogenous variables. Specifically, human resource development policy serves as a moderator in the structural model. Latent variables were represented with circles whilst their corresponding manifest variables were represented with boxes in the structural model illustrated in Figure 2.

\section{Results and Discussion}

The discussion in this section is based on the results that emanated from the test of formulated hypotheses. This discussion is necessary as a scientific contribution to knowledge on entrepreneurial culture as a tool for 
sustainable competitive advantage in the Nigerian banking sector. The correlation matrix among the major constructs investigated is presented in Table 2. The Pearson's product moment correlation coefficient between entrepreneurial culture and human resource development policy fulfils the first research objective of this study.

Table 2: Results of bi-variate correlation and scale reliability with descriptive analysis

\begin{tabular}{|c|c|c|c|c|c|c|}
\hline & Variables & Mean & Std. Deviation & 1 & 2 & 3 \\
\hline 1 & Entrepreneurial culture & 13.3344 & 2.10879 & (798) & & \\
\hline 2 & HR development policy & 47.8361 & 7.38504 & $.476^{* *}$ & $(.907)$ & \\
\hline 3 & Sustainable competitive advantage & 18.4164 & 2.60952 & $.414^{* *}$ & $.551^{* *}$ & $(.809)$ \\
\hline
\end{tabular}

${ }^{* *}$ Correlation is significant at the 0.001 level (2-tailed). Alpha coefficient estimates are presented in the diagonal.

Relationship between entrepreneurial culture and human resource development: As illustrated in Table 2, entrepreneurial culture is positively associated with human resource development policies in the Nigerian banking sector. In specific terms, the correlation coefficient between entrepreneurial culture and HR development policy is $0.476(n=305, p<0.01)$. That is, higher levels of entrepreneurial values in the banks are associated with higher levels of learning. The correlation is significant at $\mathrm{P}$ value less than 0.01 . Statistically, the study corroborated previous studies on the ground that higher level of entrepreneurial culture is associated with higher levels of individual, team and organisational learning in the banking sector (Daneshvar \& Ramesh, 2011; Goel et al., 2010; Mondy, 2010; Mundra et al., 2011). Therefore, it can be concluded that entrepreneurial culture is positively associated with all the dimensions of learning in the Nigerian banking sector. Judging from the Pearson's correlation coefficient and the level of significance, hypothesis one (H1) was supported, which means that there is a significant relationship between entrepreneurial culture and human resource development policies in the Nigerian banking sector.

Relationship between entrepreneurial culture and sustainable competitive advantage: Table 2 illustrates the mean, the standard deviations and the correlation coefficient on the relationship between entrepreneurial culture and sustainable competitive advantage among the selected banks in Nigeria. The results show that there is a statistically significant relationship between entrepreneurial orientations or values and the sustainability of banks in Nigeria. The direction of the relationship between the variables as illustrated in Table 2 shows that higher level of entrepreneurial orientations or values is associated with a higher level of sustainable competitive advantage. Hypothesis two (H2) was supported, meaning that there is a significant relationship between entrepreneurial culture and sustainable competitive advantage. This suggests that business sustainability in the knowledge-based global economy is positively associated with entrepreneurial orientations such as creativity, innovation and proactive capabilities of the workforce (Liu, 2013; Macfarlane, 2014).

Mediating influence of human resource development on the link between entrepreneurial culture and sustainable competitive advantage: The mediating influence of human resource development programmes on the interplay between entrepreneurial culture and sustainable competitive advantage in the Nigerian banking sector was assessed using SEM via IBM SPSS statistics AMOS version 23. SEM is instrumental in testing the structural associations among variables; it gives pictorial modelling of observed and unobserved variables and also examines several associations concurrently in a model (Škerlavaj, Song, \& Lee, 2010). Baron and Kenny (1986, cited in Hung et al. (2010, p. 289) emphasise that SEM is "the most efficient and least problematic means of testing mediation". This suggests the value of utilising SEM in testing the mediating influence of human resource development programmes on the interplay between entrepreneurial culture and sustainable competitive advantage in the Nigerian banking sector. The goodness of the proposed model was assessed by the model fit indices. The authors adopted chi-square value, degree of freedom, the corresponding P value, chi-square per degrees of freedom, Comparative fit Index (CFI), Non-Normed fit Index (NNFI), Tucker-Lewis fit Index (TLI), Incremental Fit Index (IFI), Goodness of Fit Index (GFI), and Root Mean Square Error of Approximation (RMSEA). All of these are used most often to assess model fit (Černe, Jaklič, \& 
Škerlavaj, 2013; Hung et al., 2010; Katou \& Budhwar, 2010). The measurement model fit indices comprising those three latent variables and their corresponding manifest variables are presented in Table 3.

Table 3: Assessment of the measurement model fit to the data

\begin{tabular}{llllllllll}
\hline $\begin{array}{l}\text { Model fit } \\
\text { indices }\end{array}$ & CMIN & DF & CMIN/DF & RMSEA & GFI & NFI & IFI & TLI & CFI \\
\hline $\begin{array}{l}\text { Measurement } \\
\text { model }\end{array}$ & 91.118 & 49 & 1.860 & 0.053 & 0.952 & 0.932 & 0.967 & 0.956 & 0.967 \\
\hline
\end{tabular}

Figure 2: Structural model explaining the mediating influence of HRDP on the link between entrepreneurial culture and sustainable competitive advantage

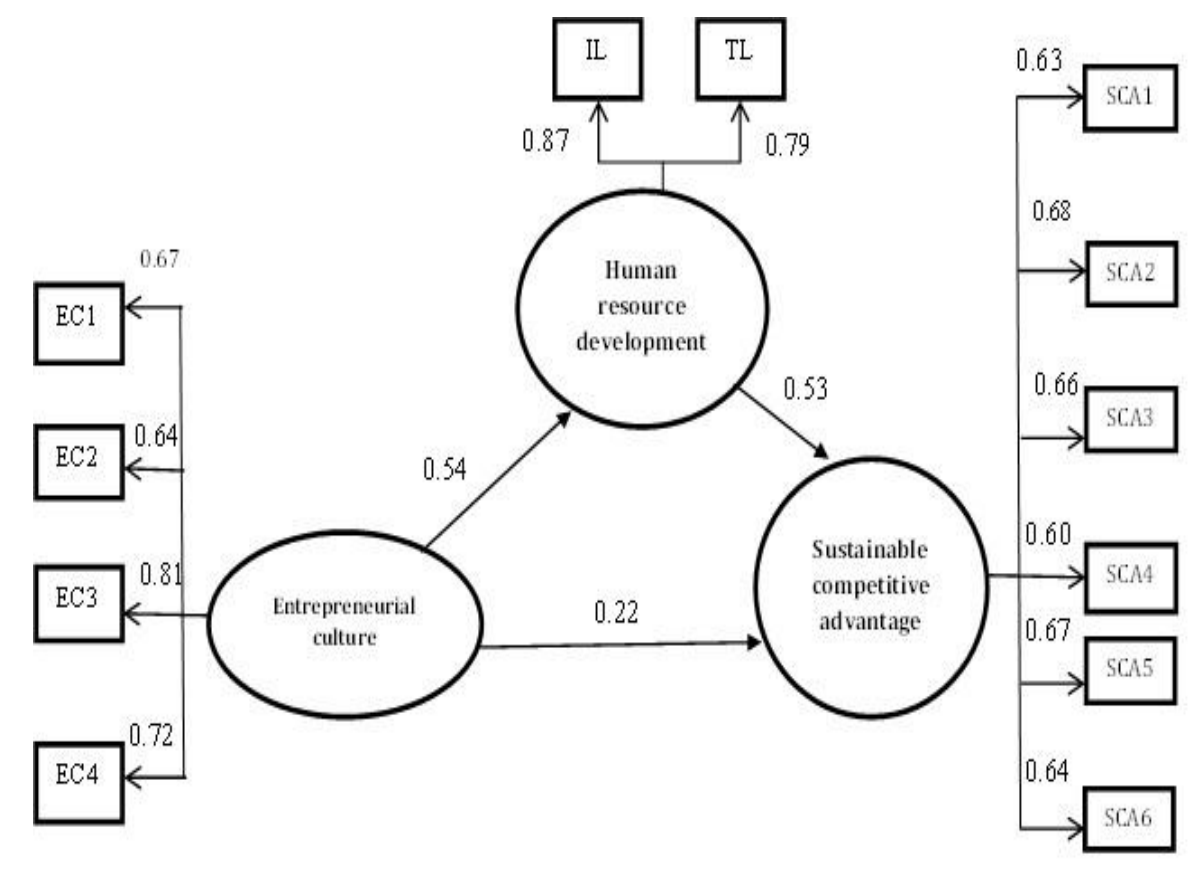

All model fit indices provided in Table 3 indicated acceptable results in terms of the psychometric properties of the latent and manifest variables investigated. This shows that approximately $95 \%$ of the variances and covariances of the proposed model could be explained by the collected data (GFI $=.952)$. Statistically, all the factor loadings of latent and manifest variables ranged from .609 to .872, which confirmed the construct validity of the proposed model. The structural model produced the following model fit indices: CMIN (chisquare) $=109.290 ; \mathrm{df}=51 ; \mathrm{p}<.001 ; \mathrm{CMIN} / \mathrm{DF}=2.143 ; \mathrm{GFI}=.942 ; \mathrm{NFI}=.919 ; \mathrm{IFI}=.955 ; \mathrm{TLI}=.941 ; \mathrm{CFI}=$ .954; RMSEA $=.061$. As illustrated in Figure 2, the boxes indicate independent (exogenous) or dependent (endogenous) manifest variables and/or mediating variables, while the circles represent their respective latent variables. The arrows linking the latent variables in the structural model constitute the operational associations between corresponding variables. The Beta loadings from one latent variable to another in the structural model can be referred to as estimated/standardised coefficients (ESC) or standardised regression weights (SRW). The underlying goodness of fit indices suggests a good fit of the structural model to the collected data. EC1, EC2, EC3 and EC4 are manifest variables measuring creative, innovative, proactive and competitive aggressiveness capabilities respectively. IL and TL measured individual and team learning respectively. SCA1 to SCA6 are manifest variables for the endogenous variable measuring competitive advantage, market share, profitability, efficiency, sales revenue and customer satisfaction respectively.

Entrepreneurial orientations or values were shown to have a strong, direct and positive influence on human resource development policies $(E S C=0.543, \mathrm{p}<0.001$ ). Similarly, human resource development policies have a positive influence on sustainable competitive advantage (ESC $=0.535 \mathrm{p}<0.001$ ). Entrepreneurial culture, 
on the other hand, significantly and positively contributed to sustainable competitive advantage (ESC $=0.218$, $\mathrm{p}=0.005$ ). However, all effects (total, direct and indirect effects) on the link between the variables in the structural model are significant. This suggests that there is a partial mediation in the structural model illustrated in Figure 2. Human resource development programmes partially mediated the relationship between entrepreneurial culture and sustainable competitive advantage in the Nigerian banking sector. Hypothesis three (H3) was supported on the ground that human resource development programmes partially mediated the relationship between entrepreneurial culture and sustainable competitive advantage in the Nigerian banking sector.Statistically, the indirect path from entrepreneurial culture to sustainable competitive advantage better explains the variations in business sustainability utilising learning and development programmes as mediating variable.

\section{Conclusion and Recommendations}

The overall objective of the research reported in this paper was to investigate the relationship between entrepreneurial culture and business sustainability in the Nigerian banking sector. The specific objectives were to assess the influence of entrepreneurial culture on human resource development policies and sustainable competitive advantage. The mediating influence of human resource development programmes on the link between entrepreneurial culture and sustainable competitive advantage was also assessed. The findings suggest that an entrepreneurial culture is positively associated with human resource development programmes and sustainable competitive advantage in the Nigerian banking sector. Statistically, the findings reveal that human resource development partially mediates the relationship between entrepreneurial culture and sustainable competitive advantage. Three major conclusions were drawnbased on the empirical evidence provided in the results and discussion section. The first conclusion was drawn on the statistics that there were significant positive relationship between entrepreneurial values and human resource development programmes in the Nigerian banking industry. This implies that creative, innovative and proactive capabilities were generally enhanced at individual and team levels in the Nigerian banking sector. Secondly, this paper concludes that there was a moderate positive relationship between entrepreneurial culture and sustainable competitive advantage in the Nigerian banking industry. This implies that creative, innovative and proactive capabilities as a set of entrepreneurial orientation moderately influenced sustainable competitive advantage in the Nigerian banking industry. The established bases for sustainable competitive advantage in the banking sector include; market shares, return on sales, profitability efficiency, customer satisfaction and productivity. The third conclusion drawn from the findings show that learning at individuals and teams' levels partially mediated the interplay between entrepreneurial orientations and sustainable competitive advantage in the Nigerian banking industry. Human resource development programmes were significantly associated with competitive advantage and explained the variations in business sustainability much better.

The management implications derived from the findings are the significance of entrepreneurial culture, facilitated through learning and development of the workforce, culminating in business sustainability in the knowledge-based global economy. Therefore, the major challenge in the present business environment has to do with sustainability, which could be overcome by enhancing creativity, innovation and proactive capabilities of employees through continuous learning and development programmes at individual, team and organisational levels. In this way, new skills are acquired, competences are developed, better attitudes and work behaviours are encouraged, leading to increased market share, return on sales, efficiency, productivity, profitability, customers' satisfaction and retention. Based on the outcomes of this research, the foregoing are indicators of sustainable competitive advantage in the Nigerian banking sector. The outcomes suggest an enhancement of entrepreneurial orientations or values through continuous learning and development programmes in order to achieve sustainable competitive advantage.

Entrepreneurial orientations, which are essential to a successful corporate entrepreneurship, are often developed in line with business strategies and/or needs. For example, the development of new products in line with customers' current and future needs require entrepreneurial orientations such as creativity, innovation, and proactive capabilities. These capabilities are best acquired or developed through continuous learning and development exercises both within and outside the organisation. It is apparent that 
entrepreneurial orientations are better acquired or communicated to employees through frequent learning and development programmes. Ambidextrous organisations/banks will require entrepreneurial orientations as well as regular learning and development programmes in the process of exploring and exploiting both current and future business opportunities. This is the true nature of sustained competitive advantage in the service industry, and it is crucial for any bank that wants to remain in business in the knowledge-based global economy. Continuous development and adequate retention of human resources in the banking industry could be used as a source of business sustainability. This approach will require excellent human capital retention strategies for banks that are willing to take up this challenge to achieve sustainable competitive advantage. Effective human capital retention strategies are necessary to avoid developing human capital for the competitors in the banking industry.

Limitation and future research: The research reported in this article focused only on the relationship between entrepreneurial culture and sustainable competitive advantage in the Nigerian banking sector. The mediating influence of human resource development programmes was also examined in the interplay between the two variables. Submissions in this article are limited to empirical evidence in the Nigerian banking sector, and it is suggested that similar research may be carried out in other sectors of the Nigerian economy, for example, in the manufacturing sector. The methodological shortcoming of this research was the use of a cross-sectional approach. Future studies may consider a longitudinal approach, which is more appropriate in inferring cause and effect on the link between/among variables.

Acknowledgement: This paper is based on a PhD study at the University of KwaZulu-Natal. Dr Fields was the supervisor of the study.

\section{References}

Aaker, D. (2012). Four Strategies for Staying Relevant. Harvard Business Review. https://hbr.org/2012/05/four-strategies-for-staying-re

Anderson, K. (1992). The purpose at the heart of management. Harvard Business Review, 70(3), 52-62.

Armstrong, M. (2009). Armstrong's handbook of human resource management, (11th ed.). London: Kogan Page.

Atiku, S. O., Chitakunye, P. \& Fields, Z. (2014a). Consensual and Entrepreneurial Culture: Insights from Organisational Culture and Human Resource Development Policy in Nigerian Banks. Mediterranean Journal of Social Sciences, 5(20), 101-113.

Atiku S. O., Chitakunye, P. \& Fields, Z. (2014b). Influence of Organisational Learning and Human Resource Outcomes on Commercial Banks' Performance in Nigeria. J Soc Sci, 40(1), 9-20.

Atiku S. O. (2014). The Relationship between Organisational Culture and Performance: A case of the Banking Sector in Nigeria. PhD Thesis, Unpublised. Durdan: University of KwaZulu-Natal.

Baker, W. E. \& Sinkula, J. M. (1999). Learning Orientation, Market Orientation, and Innovation: Integrating and Extending Models of organizational Performance. Journal of Market Focused Management, 4(4), 295308.

Beugelsdijk, S. (2007). Entrepreneurial Culture, Regional Innovativeness and Economic Growth. Journal of Evolutionary Economics, 17(2), 187-210.

Bhatt, G. D. (2000). An Empirical Examination of the Effects of Information Systems Integration on Business Process Improvement. International Journal of Operations \& Production Management, 20(11), 13311359.

Boso, N., Story, V. M. \& Cadogan, J. W. (2013). Entrepreneurial Orientation, Market Orientation, Network Ties, and Performance: Study of Entrepreneurial Firms in a Developing Economy. Journal of Business Venturing, 28, 708-727

Cameron, K. S., Quinn, R. E., DeGraff, J. \& Thakor, A. V. (2006). Competing Values Leadership: Creating Value in Organizations. MA: Elgar Northampton.

Černe, M., Jaklič, M. \& Škerlavaj, M. (2013). Decoupling Management and Technological Innovations: Resolving the Individualism-Collectivism Controversy. Journal of International Management, 19(2), 103-117. 
Cheung, S. O., Wong, P. S. P. \& Lam, A. L. (2012). An Investigation of the Relationship between Organizational Culture and the Performance of Construction Organizations. Journal of Business Economics \& Management, 13(4), 688-704.

Covin, J. G. \& Miles, M. P. (1999) Corporate entrepreneurship and the pursuit of competitive advantage. Entrepreneurship Theory and Practice, 24(1), 47-63.

Daneshvar, P. \& Ramesh, H. N. (2011). Gaining Competitive Advantage through Quality of Internet Banking Services -- An Empirical Study in the Indian Private Bank Sector. Journal of Marketing \& Communication, 6(3), 34-43.

Della Corte, V. \& Aria, M. (2016). Coopetition and sustainable competitive advantage. The case of tourist destinations. Tourism Management, 54, 524-540.

Deshpande, R. \& Farley, J. U. (1999). Corporate Culture and Market Orientation: Comparing Indian and Japanese Firms. Journal of International Marketing, 7(4), 111-127.

Deshpande, R. \& Farley, J. U. (2004). Organizational Culture, Market Orientation, Innovativeness, and Firm Performance: An International Research Odyssey. International Journal of Research in Marketing, 21(1), 3-22.

Dess, G. G., Lumpkin, G. T. \& McGee, J. E. (1999). Linking corporate entrepreneurship to strategy, structure and process: suggested research directions. Entrepreneurship Theory and Practice, 24(1), 85-102.

Engelen, A. (2010). Entrepreneurial Orientation as a Function of National Cultural Variations in two Countries. Journal of International Management, 16(4), 354-368.

Evans, N. G. (2016). Sustainable competitive advantage in tourism organizations: A strategic model applying service dominant logic and tourism's defining characteristics. Tourism Management Perspectives, 18, 14-25.

Ezirim, C. B., Nwibere, B. M. \& Emecheta, B. C. (2010). Organisational Culture and Performance: The Nigerian Experience. International Journal of Business \& Public Administration, 7(1), 40-56.

Ezirim, C. B., Nwibere, B. M. \& Emecheta, B. C. (2012). The Influence Of Corporate Culture on Organisational Commitment: The Nigerian Experience. International Journal of Business \& Public Administration, $9(3), 155-180$.

Fayolle, A., Basso, O. \& Bouchard, V. (2010). Three Levels of Culture and Firms' Entrepreneurial Orientation: A Research Agenda. Entrepreneurship \& Regional Development, 22(7/8), 707-730.

Floyd, S. W. \& Wooldridge, B. (1999). Knowledge creation and social networks in corporate entrepreneurship: the renewal of organizational capacity. Entrepreneurship Theory and Practice, 24(1), 123-143.

George, D. \& Mallery, P. (2003). SPSS for Windows Step by Step: A Simple Guide and Reference 11.0 update (4th ed.). Boston: Allyn \& Bacon.

Goel, A., Rana, G. \& Rastogi, R. (2010). Knowledge Management as a Process to Develop Sustainable Competitive Advantage. South Asian Journal of Management, 17(3), 104-116.

Grant, R. M. (1996). Toward a Knowledge-Based Theory of the Firm. Strategic Management Journal, 17, 109122.

Harrington, J. (1991). Business Process Improvement: The Breakthrough Strategy for Total Quality, Productivity and Competitiveness. NewYork, USA: McGrawHill.

Huang, S. K. \& Wang, Y. L. (2011). Entrepreneurial Orientation, Learning Orientation, and Innovation in Small and Medium Enterprises. Procedia-Social and Behavioral Sciences, 24, 563-570.

Hung, R. Y. Y., Yang, B., Lien, B. Y. H., McLean, G. N. \& Kuo, Y. M. (2010). Dynamic Capability: Impact of Process Alignment and Organizational Learning Culture on Performance. Journal of World Business, 45(3), 285-294.

Katou, A. A. \& Budhwar, P. S. (2010). Causal Relationship between Human Resource Management Policies and Organisational Performance: Evidence from the Greek Manufacturing Sector. European Management Journal, 28(1), 25-39.

Keh, H. T., Nguyen, T. T. M. \& Ng, H. P. (2007). The Effects of Entrepreneurial Orientation and Marketing Information on the Performance of SMEs. Journal of Business Venturing, 22(4), 592-611.

Li, Y. H., Huang, J. W. \& Tsai, M. T. (2009). Entrepreneurial Orientation and Firm Performance: The Role of Knowledge Creation Process. Industrial Marketing Management, 38(4), 440-449.

Lisboa, A., Skarmeas, D. \& Lages, C. (2011). Entrepreneurial Orientation, Exploitative and Explorative Capabilities, and Performance Outcomes in Export Markets: A Resource-Based Approach. Industrial Marketing Management, 40(8), 1274-1284. 
Liu, Y. (2013). Sustainable Competitive Advantage in Turbulent Business Environments. International Journal of Production Research, 51(10), 2821-2841.

Lumpkin, G. T. \& Dess, G. G. (1996). Clarifying the entrepreneurial orientation construct and linking it to performance. Academy of Management Review, 21(1), 135-172.

Macfarlane, M. A. (2014). Sustainable Competitive Advantage for Accountable Care Organizations. American College of Healthcare Executives, 59(4), 263-271.

Mahadea, D. \& Youngleson, J. (2013). Entrepreneurship and small business development. Cape Town: Pearson Education South Africa (Pty) Ltd

Martin, B. C., McNally, J. J. \& Kay, M. J. (2013). Examining the Formation of Human Capital in Entrepreneurship: A Meta-Analysis of Entrepreneurship Education Outcomes. Journal of Business Venturing, 28(2), 211-224.

Mashhadi, F., Azar, A. \& Shahin, A. (2015). Proposing a Method for Implementing Business Process ReEngineering. International Journal of Services and Operations Management, 20(4), 123-141.

Mello, J. A. (2011). Strategic Management of Human Resources (3rd ed.). Canada: Nelson Education Ltd.

Mondy, R. W. (2010). Human Resource Management (11th ed. ed.). Upper Saddle River, New Jersey: Pearson/Prentice Hall.

Moreno, A. \& Casillas, J. C. (2008). Entrepreneurial orientation and growth of SMEs: a casual model. Entrepreneurship and Theory in Practice, 32(3), 507-528

Mundra, N. Gulati, K. \& Vashisth, R. (2011). Achieving Competitive Advantage Through Knowledge Management and Innovation: Empirical Evidences from the Indian IT Sector. IUP Journal of Knowledge Management, 9(2), 7-25.

Nkosi, T. (2011). Corporate entrepreneurship and organisational performance in the Information and Communications Technology Industry. University of the Witwatersrand: Masters disseration.

Nwibere, B. M. (2013). The Influence of Corporate Culture on Managerial Leadership Style: The Nigerian Experence. International Journal of Business \& Public Administration, 10(2), 166-188.

Pallant, J. (2011). SPSS Survival Manual: A Step by Step Guide to Data Analysis using SPSS (4 ed.). Australia: Allen \& Unwin.

Pérez-Luño, A., Wiklund, J. \& Cabrera, R.V. (2011). The Dual Nature of Innovative Activity: How Entrepreneurial Orientation Influences Innovation Generation and Adoption. Journal of Business Venturing, 26(5), 555-571.

Pollitte, W. A., Miller, J. C. \& Yaprak, A. (2015). Returns to US Firms from Strategic Alliances in China: A Knowledge-Based View. Journal of World Business, 50(1), 144-148.

Principia Group. (2011). Why Banks Should Focus on Culture, Now More Than Ever. http://www.theprincipiagroup.com/downloads/Why-Banks-Should-Focus-On-Culture-v2.pdf

Rothaermel, F. T. \& Hess, A. M. (2007). Building Dynamic Capabilities: Innovation Driven by individual-, Firm-, and Network-Level Effects. Organ. Sci., 18(6), 898-921.

Russell, R. D. (1999). Developing a process model of intrapreneurial systems: a cognitive mapping approach. Entrepreneurship Theory and Practice, 24(1), 65-84.

Sanusi, L. (2012). Banking Reform and its Impact on the Nigerian Economy. CBN Journal of Applied Statistics, $2(2), 115-122$.

Sevrani, K., Gorica, K. \& Kordha, E. (2013). Analyzing of Entrepreneurial Dimensions in Albanian Banking Systems - Some Improvement from Information Technology Paper presented at the Global Conference on Business and Finance Proceedings.

Shihab, M. R. \& Lestari, A. A. (2014). The Impact of Customer Knowledge Acquisition to Knowledge Management Benefits: A Case Study in Indonesian Banking and Insurance Industries. IEEEXplore

Škerlavaj, M., Song, J. H. \& Lee, Y. (2010). Organisational Learning Culture, Innovative Culture and Innovations in South Korean Firms. Expert Systems with Applications, 37(9), 6390-6403.

Srivastava, M., Franklin, A. \& Martinette, L. (2013). Building a Sustainable Competitive Advantage. Journal of Technology Management \& Innovation, 8(2), 47-60.

Sudarmo, P. D. (2013). Influence Business Principles, Organizational Culture, Fundamental Safe Work Practices, Operational Excellence Expectations, and Corporate Commitment to the Tenets of Corporate Operations and Corporate Performance Oil and Gas Chevron Indonesia. Journal of Accounting, Business \& Management, 20(1), 71-90. 
Wang, X., Yang, B. \& McLean, G. N. (2007). Influence of Demographic Factors and Ownership Type upon Organizational Learning Culture in Chinese Enterprises. International Journal of Training and Development, 11(3), 154-165.

Wang, W. C., Lin, C. H. \& Chu, Y. C. (2011). Types of Competitive Advantage and Analysis. International Journal of Business and Management, 6(5), 100-104.

Watkins, K. E. \& Marsick, V. J. (1993). Sculpting the Learning Organization: Lessons in the Art and Science of Systemic Change. Jossey-Bass: San Francisco.

Watkins, K. E. \& Marsick, V. J. (2003). Making Learning Count! Diagnosing the Learning Culture in Organisations. Califonia: Sage publication.

Yiu, D. W. \& Lau, C. (2008). Corporate entrepreneurship as resource capital configuration in emerging market firms. Entrepreneurship theory and Practice, 32(1), 37-57.

Zahra, S. A. \& Garvis, D. M. (2000). International corporate entrepreneurship and firm performance: the moderating effect of international environmental hostility. Journal of Business Venturing, 15, 469-492.

Zivanovic, M. \& Zivanovic, N. (2015). Business Process Improvement Application of Modern Management Techniques. Ekonomika, Journal for Economic Theory and Practice and Social Issues, 61(1), 183-192. 